\title{
Ebeveynlik ve Dijital Medya: Anneliğe İlişkin Yaratılan Yeni Temsiller ve Dayanışma Örüntüleri
}

\author{
Parenthood and the Digital Media: New Representations of Maternity and \\ Solidarity Patterns
}

\section{Meral TIMURTURKAN *}

Öz: Anneliğin değişmeyen bir doğası olduğu kadar, farklı toplumsal yapı ve kültürler içinde değişebildiği ve her dönemin kendine özgü annelik söylemi olduğu önemli bir tartışma konusudur. Annenin çocuğuna iyi bakması, emzirmesi ve çocuğun temel bakımını iyi sağlaması her dönemde evrensel bir hakikat olarak sunulmuş ve öğütlenmiştir. Günümüzde ise kapitalizm, teknoloji ve ataerkil ideoloji anneliği; yoğun çaba gerektiren, standartlaştırılabilecek ve satın alınabilecek bir tüketici formu olarak tanımlamaktadır. "İyi" annenin sınırları, çocuğu için en doğru kararı verdiği ve seçimi yaptığı ölçüye göre belirlenmekte ve bunun için çok sayıda yöntem, araç ve teknoloji hizmete sunulmaktadır. Bunların başında son yıllarda hızla çoğalan özel ebeveynlik siteleri ve uygulamaları gelmekte; özellikle anne adayları ve anneler için özelleştirilmiş birçok uygulama ve sosyal paylaşım ağları da oluşturulmaktadır. Çok sayıda reklamın, ürünün ve hizmetin tanıtıldığı bu siteler; aynı zamanda kadınların kaygılarını paylaştığı, sorunlarına çözüm aradığı, yeni dayanışma pratiklerinin ortaya çıktığı ve farklı annelik biçimlerinin müzakere edildiği alanlara da dönüşmektedir. Bu bağlamda söz konusu çalışma; günümüzde dijital medya tarafından nasıl bir annelik yaratıldığını ve annelerin kendileri için özelleştirilmiş siteleri neden kullandıkları üzerine bir tartışma yürütmeyi amaçlamaktadır. Nitel içerik analizi ile "anneysen.com" adlı site incelenmiş, anneliğin bir tüketici formuna nasıl dönüştürüldüğü ve deneyimlerini, sorunlarını, yalnızlıklarını paylaşmada sitenin annelere nasıl aracılık ettiği tartışılmıştır.

Anahtar sözcükler: Annelik, Dijital Medya, Annelik Söylemleri, Dayanışma, Tüketim

Abstract: Although maternity has an unchanging nature, it is an important matter of debate as to if it might change within different social structures and cultures and in every period has its own expression of maternity. In every time period, it has been advised and presented as a universal truth that a mother should take good care of its child, breastfeed, provide basic care. In the present day, capitalism, technology and patriarchal ideology identify maternity as a consumer form, which requires hard effort, and which could be standardized and purchased. The definition of being a "decent" mother is determined according to the measure by which she makes the most suitable decision and choice. Moreover, various methods, tools and technology are put into service for this purpose. Foremost among them are private parenthood websites and applications which have rapidly increased in recent years. Various applications and social networking sites which are particularly customized for mothers and mums-to-be. While these web sites introduce numerous advertisements, products and services, they also turn into spaces where women share their concerns, look for solutions to their problems, discuss different forms of maternity as new solidarity practices emerge. Within this context, the aim of this study was to discuss what kind of a maternity has been created by the digital media and the reasons why mothers to use websites customized for them through tracing the means and cultural codes regarding maternity, which have changed within the historical process. The website named "anneysen.com" has been examined through qualitative content analysis. Further, how maternity has turned into a consumer form and how this website mediates mothers for sharing their experiences, problems and loneliness is discussed.

Keywords: Maternity, Digital Media, Maternity Discourses, Solidarity, Consumption

\footnotetext{
* Dr. Öğr. Ü., Burdur Mehmet Akif Ersoy Üniversitesi, Fen-Edebiyat Fakültesi, Sosyoloji Bölümü, Burdur. mtmimurturkan@mehmetakif.edu.tr, https://orcid.org/ 0000-0002-1505-5544
} 
Günümüzde “kadınlık”ın, ağırlıklı olarak temsil ettiği doğurganlık üzerinden anlamlandırılarak, annelik üzerinden işlevsel kılındığı söylenebilir. Anneliğin, bu özelliği ile üremenin ve yaşamın maddi nesnesi olarak görülmesine neden olduğu düşünülse ve bu durum göz ardı edilmese de "anneliğin" toplumsal anlamda birçok boyutuyla irdelenmesi gereken önemli bir konu olduğu gerçeği bu çalışmanın odak noktasını oluşturmaktadır. Kadınlık ve erkekliğe dair kalıp yargıların tarihsel ve kültürel pratikler tarafından inşa edildiği bilgisi, anneliğin kültürel ve sosyal yönünü anlamamıza yardımcı olacaktır. Bu çerçevede "anneliğin" farklı zamanlarda ve yerlerde çok farklı biçimler aldığı, toplumun kadına, doğurganlığına ve dolayısıyla bu rollere yüklediği anlamdan bağımsız olarak var olmayacağı tartışılmaktadır (Gelen 1994, 3; Forcey 1994, 57; Moore 2003, 58). Feminist perspektife göre de annelik toplumsal, kültürel ve tarihsel olarak inşa edilmiş doğal olmayan kategorik bir oluşumdur (Silva 2003, 1). Bu doğal olmayan durum, yeniden üretim işlevi üzerinden anlamlandırılarak kadının statüsünün belirlenmesinde etkili olan önemli bir özellik olarak da ele alınmaktadır. Anneliğin yeniden üretim işlevi ve annelik içgüdüsü mutlak bir gerçekliğe dönüştürülürse de, üretim ve tüketim ilişkilerinde yaşanan değişim ve teknolojik gelişmeler onun anlamlarını ve pratiklerini zamanla değiştirebilmektedir.

Kadınlık kimliğini oluşturan mutlak gerçekliğin onun doğurganlığ 1 üzerinden meşrulaştırıldığı ve pekiştirildiği gerçeği göz ardı edilmemelidir. Böyle bir tartışmanın odak noktasını aynı zamanda kadının cinselliğine, bedenine ve toplumsal statüsüne ilişkin yüklenen anlamlar ve kadının doğurganlığının tanımlanma biçimleri oluşturmaktadır. Bu durum Rothman'ın (1994) belirttiği gibi ataerkil ideoloji, kapitalizm ve teknolojinin birbirine eklemlenerek yeni kadınlık ve annelik rolleri yaratmasını da beraberinde getirir. Farklı kültürlerin ve toplumların, üzerine farklı söylemler geliştirdiği ve bir toplumsal ilişki biçimine dönüştürdüğü annelik, hem bir üretim alanı hem de bir tüketim pratiğine dönüştürülmeye başlanmıştır.

Kadının bedeninin, cinselliğinin ve doğurganlığının önemini fark eden tüketim kültürünün aktörleri, çok çeşitli ürün ve hizmet alanlarını içeren yeni pazarlar oluşmasına aracılık ederek, anneliğin bir deneyim olmanın ötesine geçmesini sağlamakta ve onu önemli bir kâr kaynağına dönüştürmektedir. Böylelikle annelik; müzakere edilecek, tartışılacak, sınırları belirlenebilecek ve yeniden üretilebilecek bir mücadele alanına da dönüşmektedir. Önemli bir bilgi kaynağı olan internet ve akıllı telefonların gelişmesi; yeni annelik biçimlerinin ortaya çıkmasına kaynaklık etmiş, çok sayıda hamilelik, sağlık, ebeveynlik siteleri ve uygulamaları, annelik blogları, çevrim içi gruplar ve sosyal ağlar oluşmaya başlamıştır. Geleneksel annelikten dijital anneliğe kayan bir eğilimin oluşmaya başlandığı, bilginin her an ve her yerde ulaşılabilir olduğu internet çağında kadınlar; merak ettikleri, ilk kez deneyimledikleri alanlarda yaşadıkları sorunları hem danışabildiği hem de tartışabildiği mecralarda hızla yer almaya başlamaktadır. İnternet artık sadece bilgi kaynağı olarak görülmemekte, aynı zamanda sosyal paylaşım siteleri ve çevrim içi gruplar aracılığıyla yalnızlık, çaresizlik ve dertlerin paylaşıldığı önemli bir alan olarak da kabul edilmektedir. Anneliğin ilk dönemi kadınlar için sosyal, kültürel ve bireysel anlamda yeni rollerine ilişkin pratikler açısından zor bir süreç olarak tanımlanabilir. Özellikle ilk aylar; sevgi, nefret gibi karmaşık ve çelişik duygular içinde olabilmektedirler (Lupton 2000). Bu konuda yapılan ampirik çalışmalar, bebekleri ve küçük çocukları olan annelerin, diğer annelerle tanışma firsatı bulma, tecrit ve can sıkıntısını hafifletme, sorunlanını paylaşma amacıyla sosyal medyayı kullandıklarını ve önemsidekilerini ortaya koymaktadır (Gibson \& Han 2013; Lupton 2016; Lupton et al. 2016). Bu bilgi; anneliğin dijital alanlarda nasıl üretildiğine eklemlenerek, internette yer alan sosyal paylaşım ağlarını önemli bir veri kaynağı olarak görmemizi sağlamaktadır.

Söz konusu bu çalışmanın amacı; anneliğin tarihsel dinamikler ışı̆̆ında şekillenen ve söylemsel olarak inşa edilebilen bir alan olduğu gerçeğini göz ardı etmeden, günümüzde ebeveynlik ve özellikle annelere yönelik sitelerin hangi anlam ve içeriği barındırdığı, kadınların tartışma gruplarında aktif olarak var olma nedenleri ve biçimlerini nitel bir analizle ortaya koymaktır. 
Çalışmada hem anne olmak isteyen ve anne olan kadınlara yönelik kendi içeriğini sunan, hem de üye kadınlara soru sorma, kendi aralarında tartışma grubu oluşturma imkanı sunan "anneysen.com" isimli internet sitesi örneklem olarak seçilmiştir. Bu bağlamda çalışma; iki yönlü bir tartışmayı içererek, söylemsel olarak nasıl bir annelik yaratıldığını (editörler tarafından) ve kadınların orda var olma nedenlerini analiz etmeyi amaçlamaktadır.

\section{Anneliğin Toplumsal Görünümleri ve Farklı Annelik Söylemleri}

Kadın kimliğini belirleyen ve tarihsel süreç içinde çeşitli dinamikler 1şığında şekillenen farklı annelik söylemlerinin, toplumsal ilişki biçimlerini ve kadının statüsünü etkilediği bilinmektedir. Badinter $(1992,15)$ anneliğe ilişkin hem tarihsel hem kültürel bir tartışma yürüterek, kadınların siyasal ve sosyal kimliğinin; annelik rollerini nasıl üstelendikleri ve bu rollerin gerektirdiği davranış kalıplarının ne kadar yerine getirildiği ile ilgili olduğunu vurgulamıştır. Çalışmasını 18. yüzyıldan başlayarak bu alandaki bulguları analiz etmek üzerine temellendiren Banditer, bu dönemde anneliğin toplumsal anlamda yüceltildiğini ve annelik sevgisi adı altında söylemler geliştirildiğini ifade etmiştir. Kadının çocuğuna iyi bakması, emzirmesi ve çocuğun temel bakımını iyi sağlaması en önemli görevlerin başında sunulmuş ve öğütlenmiş; o dönemin temel taleplerinden olan kadınlara vatandaşlık hakkının verilmesi bu temel görev ve sorumluğun iyi bir şekilde yerine getirilmesi koşuluna bağlanmıştır. Annelik sevgisine ilişkin oluşturulan söylem güçlenerek devam etmiş, anneliğin içgüdüsel olduğu ve kadınların bunun doğal sonucu kendilerini çocuklarına tamamıyla adaması gerektiği fikri benimsenmiştir. İnsanlığın en eski tarihinden başlayarak her döneme ait annelik mitini tartışan Thurer'e (1994) göre, Taş Devri’nde içgüdüleriyle hareket eden "doğal anne"; Neolitik Çağ'da ise "kutsallaştırılmış- yüce anne"; tarihin başlangıcıyla birlikte "büyük-yüce" anneliğin mitinin yıkılışı; klasik dönemde ise ikincil konuma sahip olan kadınlar ve seçilmiş çocuklara bakmakla yükümlü "narsis anne"; Ortaçağ'da kutsal çocuğun doğuşu ile yeniden kutsanan çocuk ve annelik; erken modern dönemde her şeyi bilen baba ve "itaatkar anne"; modern dönemde "annelik iç güdüsü"; 20. yüzyılın başında ise her şeyi kural ve kitabına göre uygulayan "bilimsel anne"; 20. yüzyılın ikinci yarısından sonra ise "empatik anne" miti hakim olmuştur. Thurer tarihsel süreç içinde annenin ve çocuğun statüsünü tartışarak, "iyi anne"nin sınırlarını belirleyen temel paradigmaların ve toplumsal dönüşümlerin neler olduğunu kültürel bir perspektif içine yerleştirerek aktarır. Buradan hareketle annenin her koşulda "kendini çocuğa adaması ve güçlü olması gerektiği" ön kabulünün, hemen hemen tüm toplumsal yapılarda ve dönemlerde geçerli olduğu düşüncesinin pekiştirildiği söylenebilir.

Güçlü ve kendini adayan anne fikri 20. yüzyılın ikinci yarısında da devam etmiş, 1950'lerde çalışmayan, orta sınıf, beyaz anne modeli önemli bir söyleme dönüşmüştür. Ataerkil ideolojinin annelik miti üzerinden kendine tahakküm alanı yarattığını düşünen 2. dalga feminizmin etkisiyle bu dönemde yeniden aile ve annelik ile ilgili değerler tartışmaya açılmış ve çalışan anne miti yükselemeye başlamıştır. Bu sürecin bir sonucu olarak "iyi anne", "ideal anne", "süper anne" miti yaratılmıştır (Glenn 1994, 3; Moore 2003). Koşullar ne olursa olsun annenin kendini çocuğuna adaması gerektiği fikri bu yaratılan annelik mitleriyle daha da güçlenmekte, bu anlamda çocuk merkezli, uzman rehberliğinde, zaman alıcı ve finansal açıdan zorlu değerleri içeren yoğun anne-baba ideolojisi ivme kazanmaktadır (Hays 1996; Zhou 2017, 754). Bu süreç çocuk merkezli bir yaşamı beraberinde getirdiği gibi; kadının bütün faaliyetlerini, enerjisini, sevgisini ve bilgisini çocuğuna aktarması gerektiği fikrini ve "mükemmel" annelik mitini de birçok açıdan dayatmakta ve dile getirmektedir (Douglas \& Michaels 2004). Bu annelik miti "yoğun annelik" olarak tanımlanmış, çocuk merkezli, kendini her koşulda çocuğuna adayan ve onun için en iyi seçimler yapan kaygıll anne olarak da nitelendirilmiştir (Hays 1996). Her dönem çocuğun temel bakımı ile ilgilenen annenin kullandığ 1 yöntem ve stratejiler değişmiş, 
toplumun dayattığı roller ve beklentiler çeşitlenmiştir. İdeal annelik normları ve araçları belirlenmiş; deneyime dayanan annelik yerine kurumsallaştırılan ve standartlaştırılan annelik modelleri yaratılmaya başlanmıştır.

Anneliğin nasıl inşa edildiğine ilişkin süreçleri tartışan Rothman’a (1994) göre; kapitalizm, patriarka ve teknoloji olmak üzere üç ideolojinin bir araya gelmesi ile bu süreç mümkün olmaktadır. Bu süreçler iç içe geçerek toplumsal hayata nüfuz ettiği gibi anneliğe ilişkin temel yargı ve değerleri de etkilemektedir. Patriarkal sistem; kadınların emeği, yeniden üretim süreci ve cinsellik üzerindeki erkek egemenliğine işaret ederken, teknoloji ise; kadınlığa ait temel biyolojik süreçlerin, hamilelik, çocuk doğurma, üreme teknolojileri ve tıbbi müdahaleleri içermektedir. Kadın bedenine müdahaleyi içeren bu süreç aynı zamanda kadın bedeninin tıbbileşmesini sağlayarak, bedenin sınırlarını belirleme görevini ataerkil ideolojiden sonra tıbbın da üstlenmesine yol açmaktadır. Teknolojik ideoloji; anneliği bir meslek ve iş gibi kurarken; kadın bedenini ise üremenin bir aracı, çocuğu da kadın emeğinin sonucu üretilen bir ürün gibi görmektedir. Kapitalizm ise patriarkal ve teknolojik ideoloji ile bütünleşerek kadın üzerindeki erkek tahakkümünün kendi sistemini yeniden üretecek şekilde işlemesine neden olmaktadır.

Ailenin, sosyal ve psikolojik bir birim olmasının yanı sıra, ekonomik bir birim olduğu gerçeği göz önünde bulundurulsa, çocuğun artık bir üretim aracı olarak değil tüketim aracı olarak görülmeye başlandığı söylenebilir. Firestone’a (1993) göre patriarka ve kadının üreme işlevi, cinsiyete dayalı iş bölümüne yol açarak toplumsal cinsiyet ayrımcılığının da temel çıkış noktasını oluşturmaktadır. Bu durum kadınlığın doğasına bağlanarak ataerkil ideolojiye tahakküm alanı yaratmaktadır. Irigaray’a (2006) göre bu anlayış yaşamımızın içinde kemikleşmiş bir yapıya dönüşerek, kadının toplumsal temsiline ilişkin anlamları yeniden üretmektedir. Annelik doğal bir durum değil, aksine biyolojik farklılıkların ve heteroseksüel etkinliğin bir sonucu olarak kendini tanımlayan ve üreten bir kurum durumundadır (Smart 2003, 37). Kadının toplumsal statüsü açısından annelik önemli işleve sahip olmakta, kadınlık kimliği bu biyolojik işlev ve rol üzerinden kurulmaktadır. Böylece kadınların toplumsal konumu ve bütün gündelik faaliyetleri annelik rollerine göre belirlenmekte ve çocuğun bakımına ilişkin her süreç kadınların yükümlülügü olarak görülmektedir.

Son yıllarda farklı annelikler birbirine eklemlenerek, kadının kamusal ve özel alandaki ilişki biçimlerini şekillendirmektedir. Medya, gelişen teknolojiler, bebek bakımına ve anneliğe yönelik geliştirilen ürün ve hizmetler, özellikle internet bu ilişki biçiminin dönüşmesine neden olmaktadır. "Bilimsel annelik", "süper anne", "iyi anne" miti güçlenerek ailenin ve toplumun kadından beklentilerinin daha da artmasına neden olmaktadır. Kadının bu durum ile baş edecek yeni stratejiler ve ilişki biçimleri geliştirmesi kaçınılmaz olarak kapitalizmin ürettiği araç ve yöntemlere başvurmasını da beraberinde getirmektedir. Sosyal medya (Facebook, You Tube, Instagram), ebeveynlere yönelik doğrudan kurulan diğer sosyal medya ağları (Nurturia) ve doğrudan anneler için kurulmuş diğer siteler (anneysen.com), çeşitli bireysel bloglar bu araçların başında gelmektedir. Sadece bilgiye erişim amacıyla değil aynı zamanda destek, dayanışma ve sorunlara çözüm arayışı için başvurulan bu ağlar, ebeveynlik ilişkilerini de dönüştürmektedir.

\section{Yeni Dijital Medya ve Annelik}

Anneliğin bir deneyimden ziyade öğrenilecek ve uygulanılacak bir pratik olarak tanımlanmaya başlanması; yeni kamusallık ve dolayısıyla yeni bilgi arayışlarına ilişkin çabayı da ortaya çıkarmaktadır. Yerleşik, gelenekselleşmiş, yerel annelik formları ve çocuk yetiştirme pratikleri yerini yeni medyanın ürettiği standart hakikatlere ve ideal, genelgeçer olduğu varsayılan yeni bir forma bırakmaktadır. Medyanın farklı formlarının; bilgiyi üretmede, yaygınlaştırmada ve etkinleştirmede önemli etkiye sahip olduğu, yeni ideolojiler aracılığıyla farklı gerçeklikler inşa 
edebildiği tartışılmaktadır (Hall 1994a; 1994b). Farklı bilgi ve paylaşım araçlarının gelişmesi (yeni medya ve iletişim teknolojileri) yeni annelik ideolojilerini ve biçimlerini ortaya çıkarmakta; özellikle yeni çevrim içi uygulamalar bilginin alıcısı konumundaki annelerin artık bilginin üreticisi konumuna geçmesini ve kendi hakikatini üretme şansını elde etmesini beraberinde getirmektedir. Kadınlar; bilgi, destek, dayanışma, yeni arkadaşlıklar ve yeni içerikleri oluşturmak için sosyal paylaşım ağlarının önemli bir kullanıcısı olmaya başlamaktadır.

Yapılan çalışmalar ailelerin 1990'ların ortalarından itibaren çeşitli Web sitelerini, tartışma forumlarını ve blogları tavsiye, bilgi ve destek için kullanmaya başladığını; özellikle akıllı telefonlar, tablet bilgisayarlar ve Wi-Fi gibi mobil ortamların ortaya çıkması ile birlikte ebeveynlerin web sitelerine erişiminin, zaman ve mekana sıkışmadan daha da yaygınlaştığını göstermektedir (Lupton et al. 2016, 730-731). Özellikle sosyal medyanın ortaya çıkış1; diğer ebeveynlerle bağlantı kurma, hamilelik ve ebeveynlik deneyimlerinin kişisel detaylarını değiştirme konusunda yeni yollar sağlama ve Facebook, YouTube, Pinterest, Twitter ve Instagram gibi sosyal ağların ebeveynlere kendi materyallerini yükleme ve diğerlerinin içeriklerine yanıt verme, bunları hazırlama, etiketleme veya paylaşma firsatı sunduğu söylenebilir. Artık birçok ebeveynlik sitesi kurularak, sosyal medya sayfalarından veya profillerinden bu web sayfalarıyla bağlantı kurmaları için firsatlar sunulmaktadır. Kişisel Facebook hesaplarının yanı sıra, ebeveynler için çok sayıda özel Facebook sayfası da kurulmakta, Twitter ve Instagram üzerinden, hamileliğ e veya anneliğe ilişkin hashtag’ler (etiketler) aracılığıyla içeriğe kolayca erişebilmektedirler (Lupton et al. 2016, 730-731). Özellikle YouTube'un içerik oluşturma, hamilelik ve ebeveynlik hakkında paylaşım için merkezi bir forum haline geldiği de tartışılarak, fetüsün ve doğumun gelişim aşamalarını, bebeklerin gelişim evrelerinin ve ilk'lerinin yanı sıra, sağlık bakım ve çocuk bakım uzmanlarının bu sürece ilişkin video ve önerilerinin yer aldığ önemli mecra olduğu da ele alınmaktadır (Lupton et al. 2016, 730-731). Dijital medyada çocuk bakımı, gelişim, hamilelik, sağlık ve doğum gibi pek çok tema içeren bloglar, sosyal ağlar, kendi içinde kapalı gruplar, uygulamalar ve sitler mevcut olup ailelere merak ettikleri sorular ve sorunlar konusunda ortak bir paylaşım ve yardımlaşma sunmayı amaçlamaktadır.

Ebeveynlik teması içeren web siteleri özellikle 1990'lardan sonra hızlı bir şekilde internet ve iletişim teknolojilerine paralel olarak gelişmiş ve her geçen gün popüler olmaya devam etmiştir. $\mathrm{Bu}$ web siteleri, çoğunlukla hamilelik ve ebeveynlikle ilgili konular hakkında bilgi içerirken; kullanıcılarını da bu tür bilgiler hakkında birbirleriyle sohbet etme firsatları sunarak birleştirmektedir. Bu tarz siteler diğer sosyal medya ağlarından farklı olarak (Facebook, Instagram veya Twitter) kullanıcıların mobil cihazlarıyla bağlantı kurmasını ve sosyal medyada bir varlık oluşturmasını sağlamak için genellikle kendi özelleştirilmiş uygulamalarını sunmaktadır. $\mathrm{Bu}$ siteler İngiltere merkezli Mumsnet ve NetMums, Avustralya'daki Belly Belly ve The Bub Hub, ABD merkezli BabyCenter, CafeMom, Parents.Com ve Parenting.Com olarak siralanabilir (Alexa 2016 akt. Lupton et al. 2016, 731). Bu sitelerin ebeveynlik çalışmalarında önemli bir araştırma platformu olarak görülmesi ve çok sayıda üyeye sahip olması, konu ile ilgili araştırmacıları bu sosyal ağları bilimsel anlamda irdelemeye yöneltmiştir. Örneğin İngiltere'nin en büyük ebeveynlik sitesi olan Mumsnet, 2000 yılında doğum öncesi gruplarla bir araya gelen bir spor gazeteci ve televizyon yapımcısı tarafindan kurulmuş, ebeveynlerin bilgi ve deneyimlerini bir araya getirerek hayatlarını kolaylaştırmak temel amaç ve slogan haline getirilmiştir. Milyondan fazla aylık ziyaretçiyi alan tartışma panoları ile Mumsnet Talk, İngiltere'deki en büyük ebeveynlik sitesi olarak kabul edilmektedir (Pedersen 2016, 34; Pedersen \& Lupton 2018, 59). Bir diğer global ölçekte en büyük ebeynelik-paylaşım sitesi olan BabyCenter ayda 100 milyondan fazla kişiye ulaşan içeriğe sahip dünyanın bir numaralı dijital ebeveynlik kaynağı kabul edilmektedir. Ayrıca Amerika Birleşik Devletleri'nde bebek bekleyen veya yeni anne olan 10 kişiden 7'sinin BabyCenter'ı kullandığı belirtilmektedir. Dünyanın farklı ülkelerine de hitap eden BabyCenter'ın 
içeriğinin dokuz farklı dilde mevcut olduğu ve 50 milyondan fazla annenin BabyCenter' in 11 web sitesini her ay ziyaret ettiği belirtilmektedir (https://www.babycenter.com/about).

$\mathrm{Bu}$ sosyal mecralarda kadınlar, hamilelik ve annelikle ilgili dijital veriler üretme konusunda birçok firsata sahip olma şansı elde ederek, bloglara, çevrim içi tartışma forumlarına ve sosyal medya gruplarına içerik konusunda katkıda bulunmaktadır. Kendileri ve bebekleri için diğer dijital medyayı da (akıllı telefon uygulamaları, çeşitli web siteleri) vücut ağırlığı, sağlık, beslenme, fiziksel aktivite düzeyleri, diyet, ruh hali, ilaç tüketimi ve tıbbi randevular gibi bilgiye erişebilmek ve onu kaydedebilmek için kullanmaktadırlar (Thomas \& Lupton 2015; Lupton 2016, 2; Lupton et al. 2016). Lupton'un (2016) ebeveynlik siteleri üzerine yaptığı kapsamlı çalışmalarında dijital medyanın ve özellikle yeni sosyal medya ağlarının kadınların yaşamında önemli bir bilgi aygıtına ve gündelik hayat içinde karşılaştı̆̆ sorunların çözümünde ve büyük oranda ortaya çıkan yalnızlık duygusunu aşmada etkili bir araca dönüşmeye başladığını ifade etmektedir. Yeni doğmuş bebeklerin bakım talepleriyle başa çıkmada birçok kadının belirsizlik, kararsızlık, kaygı, yalnızlık ve sosyal izolasyonu yaşadığı tartışılmakta; hamile kadınların ve annelerin interneti bilgi amaçlı kullanmanın yanı sıra, duygusal destek, diğer ebeveynlerle bağlantı kurmak ve yardım amaçlı kullandığını da ortaya koymaktadır. İnternetin ilk ortaya çıktığı yıllarda çeşitli web siteleri, çevrim içi tartışma forumları ve bloglar bu amaçlar için kullanılırken; son yıllarda ortaya çıkan farklı sosyal medya ağları ve mobil yazılım uygulamaları da (akıllı telefondaki uygulamalar) kullanılmaya başlanmıştır.

Kadınların dijital medyayı sadece bilgiye erişmek için kullanmadığı, aynı zamanda pasif bir kullanıcı olmanın ötesine geçerek herkesin ulaşabileceği bilgiyi aktif olarak oluşturabildiği ve karşılaştıkları bilgileri etiketledikleri, beğendikleri, tavsiye ettikleri, paylaştıkları ve bazen yeniden düzenledikleri görülmüştür (Lupton 2016, 2). Duggan ve Lehnhart'in (2015) yaptığı bir araştırmaya göre anneler; destek alma veya destek olma amaciyla sosyal medyayı kullanmakta, aile ve arkadaşlarla iletişim halinde olmak, bilgi toplamak ve kendileri için önemli olan şeyleri paylaşmak için bu platformlara güvenmektedirler. Aynı çalışmaya göre annelerin babalardan biraz daha sık ebeveynlik kaynağı olarak sosyal medyaya başvurdukları vurgulanmaktadır.

Sosyal paylaşım sitelerinin kullanımına ilişkin en önemli tartışmalardan bazıları da, bu teknolojilerin insanları izole edip etmediği, insanların ilişkilerini nasıl etkilediği ve başkalarına bu şekilde bağlı olmanın insanlara fayda getirip getirmediği gibi alanları kapsamaktadır. Pew Research Center ve Amerikan Hayat Projesi’nin (2011) farklı değişkinleri göz önünde bulundurarak (yaş, cinsiyet, sosyal sınıf) insanların genel sosyal ağları ve yeni iletişim teknolojilerini güven, hoşgörü, sosyal destek ve politik amaçlı kullanıp kullanmadığına ilişkin yaptıkları bir araştırmaya göre; paylaşım sitelerini kullananlar diğer insanlara daha fazla güven duymakta, daha yakın arkadaşlara sahip olmakta ve politik olaylara daha angaje olmaktadır. Özellikle sosyal paylaşım siteleri içinde Facebook kullanıcılarında bu durumun daha belirgin olduğu, aynı araştırma tarafindan ortaya konulmuştur (Hampton et al. 2011). Ayrıca bu tür araştırmalarda sosyal medyanın kullanıcılarının kimler olduğu da önemli bir tartışma sorusu olarak karşımıza çıkmaktadır. İnternet kullanımının son yıllarda tüm sosyal gruplar ve yaş gruplarında olağanüstü bir şekilde artığı vurgulanırken, ancak yeni çalışmalar kadınların ve özellikle genç kadınların internet kullanımı konusunda diğer gruplara göre daha hevesli hale geldiğini ortaya koymaktadır. Buna göre genç kadınlar interneti bloglama ve sosyal ağlar için kullanırken, biraz daha ileri yaştaki kadınların internet üzerindeki birçok ebeveynlik topluluğuna katıldığı ve özellikle annelerin önemli ve büyüyen bir internet kullanıcısı grubunu oluşturduğu da tartışılmaktadır. (NielsenNet Ratings, May1s 2007'den akt. Pedersen \& Smithson 2010, 88). İnternetin; “yeni annelere", gerçek bilgi güçlerini arttırmada ve birer "yeni anneler" olarak hayatlarında potansiyel olarak yabancılaşan, değişen bazı yönlerini iyileştirmeye yardımcı olan bir mecra ve alternatif bilgi kaynaklarına erişimde de etkili bir alan olduğu ifade edilmiştir (Madge \& 
O’Connor 2006, 28). İnternet bir yandan kadınların anneliğe geçişte gerçek anlamda güçlenme duygusunu arttıran sanal sosyal destek iken öte yandan alternatif bilgi kaynakları sağlamada merkezi bir rol oynamaktadır. Bu özelliklerin yanında internetin, eş zamanlı olarak geleneksel annelik ideolojisine ve cinsiyet rollerine ait kalıp yargıları yeniden ürettiği de söylenebilir.

\section{Araştırmanının Kapsamı ve Metodolojisi}

Çalışma, günümüzde ebeveynlik ve özellikle annelere yönelik internet sitelerinin hangi anlam ve içeriği barındırdığını, kadınların orada var olma biçimleri ve nedenlerini ele almayı amaçlamaktadır. Bu amaç kapsamında anne olmak isteyen ve anne olan kadınlara yönelik kendi özel içeriğini sunan, aynı zamanda üye kadınlara soru sorma ve kendi aralarında tartışma grubu oluşturma imkanı veren anneysen.com adlı internet sitesi örneklem olarak seçilmiştir. Sitenin bu özelliği; söylemsel olarak nasıl bir annelik yaratıldığını (editörler tarafından) ve kadınların orada var olma biçimleri ve nedenlerinin neler olduğunu tartışmaya açma imkanı sunmaktadır.

Söz konusu çalışma için seçilen "anneysen.com" adlı site doğrudan kadınlara hitap eden, hamilelik, doğum, bebek bakımı ve sağlığı, çocuk yetiştirme, annelik psikolojisi gibi konularda tartışma panoları içeren; uzman yazıları ve soru-cevaplar, çeşitli videolar ve anne tecrübeleri paylaşılan bir bilgi platformudur. Özel olarak site; çocuk etkinlik atölyeleri, eğlence merkezleri, doğum fotoğrafçıları, bakıcı hizmetleri ve hamile-bebek-çocuk araç gereçleri gibi birçok ürün ve hizmet konusunda destek ve fiyat teklifi sunmakta ve bir pazar yeri olarak da kullanılmaktadır (https://www.anneysen.com/hakkimizda). Geniş bir ağa ve ziyaretçiye sahip olan yılda 8 milyondan fazla annenin ziyaret ettiği düşünülen sitenin bu araştırma için tercih edilmesinin ardında; bir ebeveynlik sitesi olmanın ötesinde doğrudan annelere hitap etmesi; herkese açık soru-cevap tartışma panosu içermesinin yanında özellikle toplumsal cinsiyetlendirilmiş bir platform olduğunun düşünülmesidir. Çok sayıda benzer site, blog, kapalı gruplar (Facebook’ta veya Google'da yer alan emziren anneler, uykusuz anneler gibi...) ve diğer paylaşım ağları incelenmiş, benzer amaç ve içeriklere sahip oldukları gözlemlenerek dışarıda bırakılmış ve spesifik bir temsiliyet sağlaması açısından anneysen.com adlı site tercih edilmiştir.

Söz konusu site ve içerikleri, medya çalışmalarında sıklıkla kullanılan niteliksel içerik analizi ile irdelenmiş; metinlerin içerikleri, üretilen anlamlar, verilmek istenen mesajlar betimsel ve tematik bir şekilde analiz edilmeye çalışılmıştır. Nitel veri analizi araştırmacıya alandan topladığ 1 veriler içinde saklı duran bilgileri keşfetme ve anlamları açığa çıkartma imkanı sunar (Özdemir 2010, 328). Bu bağlamda sitede yer alan doküman niteliği taşıyan içerik, makale, yazışma, soru, görsel ve videolar incelenerek bir kategorik ayrıma gidilmeye çalışılmıştır. En çok üzerinde durulan, tartışılan ve ele alınan konular 1şı̆̆gnda çeşitli temalar oluşturulmuştur. Bunlardan ilki anne adaylarını ve hâlihazırda anne olanları çok sayıda ürün ve hizmetin alıcısı konumuna getiren içeriklerin tartışıldığı "bir tüketim pratiği olarak yaratılan annelik"tir. Sorunlarını, isteklerini, kaygılarını, ihtiyaçlarını ve yalnızlıklarını paylaştıkları tartışma panolarından yola çıkarak elde edilen bir diğer tema ise "bir dayanışma pratiği olarak paylaşılan annelik" temasıdır. Son olarak anneliğin bilimsel sınırlarını çizen ve uzman desteğinin yaşamın her alanında gerekli olduğunu ifade eden içeriklerden, tartışma panosundan, çok sayıda görsellerden ve videolardan yola çıkarak oluşturulan "bir uzmanlık alanı olarak yaratılan annelik" teması tartışılmaktadır. Çalışma içinde alıntılar; iletişim şeklini bire bir yansıtmak ve kadınların gündelik dildeki sohbetini sanal ortama nasıl taşıdıklarını göstermek adına yazım hataları düzletilmeden yapılmıştır

Söz konusu araştırmaya dahil edilen sosyal medya platformu anneliğin ilk aşaması olan hamilelik sürecinden başlayarak kadınlara geniş çerçevede bilgi paylaşımı ve bilgi edinme

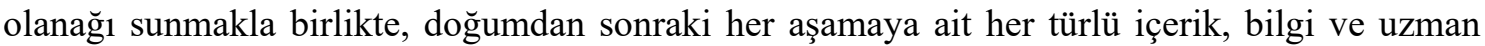
desteğine ulaşmayı mümkün kılmaktadır. "Anneliği kolaylaştırıyoruz" sloganı ile bir içerik 
sunmaya çalışan sitenin anneliği kurumsal bir zeminde tartışarak içerik sunduğu görülmektedir. Söz konusu sitenin anneliği sadece biyolojik bir süreç olarak ele almadığı, aynı zamanda anneliğin toplumsal görünümünü yansıtan içeriğe ve bilgi paylaşımına da çok sayıda rastlandığ 1 görülmektedir. Annelerin sahip olması gerektiği tutumlar, davranışlar, bebek bakım ritüelleri, beslenme, emzirme, oyun, eğitici faaliyetler, kadının kendi bedenine dair merak ettiği konular, estetik, özel ilişkileri yönetme gibi çok sayıda içerik ve bilgiye ulaşmak mümkün olmaktadır. Özellikle annelik uzman eşliğinde yürütülecek bir meslek ve kurumsal pratik gibi sunularak, teorik bir annelik ideolojisi de üretilmektedir. Bu teorik annelik ideolojisinde bilimsel yöntem ve pratikler uzman eşliğinde çeşitli sorular ve içeriklerle desteklenmektedir. İdeal annelik; uzman desteği ve belli bir çaba ile ulaşabilecek, elde edilebilecek bir pratiğe de dönüştürülebilmektedir. Günümüzde kadınlar üreme teknolojileri, doğurganlık, hamilelik ve doğumla ilgili bilgi kaynaklarındaki artan seçenek sayısından kaynaklanan bir dizi sorun ve belirsizliklerle de karşı karşıyadırlar. Bir zamanlar ailenin ve toplumun diğer kadınları tarafından edindikleri geleneksel bilginin yerini, çeşitli tıp uzmanlarından, kitaplardan, dergilerden, TV programlarından ve internetten eriştikleri bilgi almaktadır (Song et al. 2012, 774). Bu durum bir yandan bilgiye erişimi kolaylaştırırken, öte yandan çok sayıda kaynak ve bilgi yoğunluğu nedeniyle seçenekler arasında doğruya ulaşmaya yönelik sürekli tetikte ve dikkatli olmayı gerektiren bir çabayı da beraberinde getirmektedir.

\section{Bir Tüketim Pratiği Olarak Yaratılan Annelik}

Tüketim kültürü içinde önemli bir piyasa değerine sahip olan kadın bedeni; moda, estetik, sağllk olmak üzere pek çok alanın yönettiği ve yönlendirdiği bir alana dönüşmüştür. Kadının bedeninin doğrudan doğurganlığın merkezinde yer alması, aynı zamanda annelik üzerinden söylem üretilmesi ve dolayısıyla toplumsal statünün belirlenmesi söz konusudur. Anneliğin ve bedeninin her geçen gün bir tüketim pratiğine dönüşmesi ve birçok pazarın alıcısı konumuna yerleştirilmesi; doğum öncesi, hamilelik ve doğum sonrası her bir aşamanın yönetimselliğini de beraberinde getirmektedir. Söz konusu çalışmaya konu olan dijital platformların bu üç aşamayı göz ardı etmeden içerik oluşturduğu, reklam ve ürün yerleştirdiği, çok sayıda seçeneğin anne olmak isteyen ve hâlihazırda anne olan kadınlara sunduğu görülmektedir. Çoğu zaman en doğru seçeneği bulun, en iyisine sahip olun, sizin için öneri gibi başlık ve içerikler hazırlanan ve özellikle de uzman veya alanında popüler olan bir ünlü isim ile oluşturulan içerikler; kadınlara seçim yapma seçeneği sunarken, söz konusu sorumluluğu doğru biçimde üstlenmesini de telkin etmektedir. Ürün ve içerik arayan kadınlara destek niteliği taşıyan bu paylaşımlar; farklı pazarların yaratılmasına ve anneliğin önemli kâr kaynağına dönüşmesine de neden olmaktadır. "Hayatınızı kolaylaştırlyoruz”, "anneliği kolaylaştırıyoruz" "anneliğe ait tüm ihtiyaçlar burada” gibi slogan ve içeriklerle anneliğe ilişin çok sayıda içerik oluşturulmakta, ürün ve hizmet tavsiye edilmektedir.

Doğurganlığın kadının statüsünü belirleyen ve kadınlık kimliğini oluşturan önemli bir ögeye dönüştürülmesi; hamilelik planlama, yumurtlama, kısırlık ve tüp bebek gibi içeriklerin oluşturulmasına ve bu konuda destek isteyen kadınların kendi içinde farklı konu ve sorunları müzakere etmesine neden olmaktadır. "Adet Takibini Yapmanı Kolaylaştıracak 5 Mobil Regl Takvimi Uygulaması" başlığı ile mobil uygulamalar tanıtılmış, özellikle gebelik planlaması konusunda başka dijital uygulamaların reklamı yapılmıştır. "Türkiye Genelinde En Çok Tercih Edilen 10 Tüp Bebek Merkezi" başlıklı yazıda tüp bebek merkezlerinin sırasıyla tanıtımı ve reklamı yapılmadan önce görsel içeriklerle desteklenmiş “Tüp Bebek Yöntemiyle Çocuk Sahibi Olan 10 Ünlü’ başlığı ile başka bir metin oluşturulmuş ve sonraki haberin etkisini ve talep edebilirliğini artırmak amaçlanmıştır. Buna benzer içerikler hamilelik sürecinde de devam etmiş, "Ístanbul Avrupa Yakasında Kapısını Çalabileceğin 10 Hamile Beslenme Uzmanı", "Hamilelikte 
Beslenmeyi Senin İçin Sağglılı Hale Getirecek İstanbul Anadolu Yakasındaki 7 Diyetisyen”, "5 Doğum Fotoğrafçısına Bu İşin A, B, C'sini Sorduk!”, “İstanbul Anadolu Yakası 'nda Bulunan 10 Hamile Pilatesi ve Yogası Merkezi ile Doğuma En Iyi Şekilde Hazırlan!”, "Hamileliğin Balayı: 2. Trimesterde İhtiyacın Olacak 6 Şey", "Hamilelikte Illk Üç Ay: Ilk Trimesterde Ihtiyacın Olacak 7 Şey”, "En Çok Tercih Edilen Kök Hücre Merkezleri”, "Ona Teşekkür Borçlusun: Hamile Külotu”, “Tüm Hamilelerin Ortak Sorusu: En Iyi Çatlak Kremi Hangisi?...” gibi çarpıcı başlıklarla daha pek çok ürün ve markanın önerisi, reklam ve tanıtımı yapılmıştır.

Benzer içerikler doğum sonrası, emzirme dönemi ve çocuğun bakımı gibi temel alanlarda oluşturulmaya devam edilerek, çok sayıda ürün, destek, uzman, organizasyon ve aktivite önerilerinde bulunulmaktadır. Baby shower partisi mekanı, baby shower butik pasta, hamilelikte sağlıklı beslenme uzmanı, doula ve doğuma hazırlık mekanı, bebek bakıcısı hizmeti, 1 yaş doğum günü butik pasta, yeni doğan bebek fotoğrafçısı, emzirmede beslenme uzmanı, 1 yaş doğum günü için organizasyon, spor salonu, çocuk atölyesi ve oyun grubu, çocuk eğlence merkezi, çocuk müzik ve sanat merkezi gibi farklı kategorilerde pazarlar oluşturulmakta ve fiyat teklifleri de sunulmaktadır. Sadece sitenin kendi oluşturduğu pazar yeri ve reklamlar aracılığıyla değil aynı zamanda tartışma panolarını takip eden çeşitli uzmanlar, kişiler veya firmalar tarafından da birçok yeni ürün önerisi, hizmet satışa sunulmaktadır. Aşağıdaki soru ve cevap biçiminde gerçekleşen iletişim, sorunu dile getirme, uzmana yönlendirme, bilgi içeriği ve reklam gibi ögeleri içeren çarpıcı bir örnek olarak süreci ifade etmektedir:

"Merhaba 29 aylık kızım var dil gelişimi sıkıntılı 3 lü 5 li cümle kurması lazım hala 2 li cümle anne al anne ver zorlarsam konuşuyor yoksa hiç yok oyun grubuna $m i$ gitse daha etkili olur konusma terapisti mi gerçekten cok üzülüyorum tedirginim 3 yaşına girecek daha tık yok"

"MrvErkn Size de yardımcı olmaya çalışalım. lütfen irtibata geçiniz."

"ben Özel eğitim öğretmeniyim endişelenecek bir şey yok bence tabi çocuğu görmek gözlemlemek gerekiyor ama oyun terapisine götürün veya yarım gün anaokulu kreş gibi yerlere vererek bunu çözümleyebilirsiniz eğer isterseniz içiniz rahat olacaksa benimle iletişime geçebilirsiniz yardimcl olabilirim" (https://www.anneysen.com/1-6-yas-cocuk/soru-cevap/ çocuk-gelisimi-dil-gelisimi20190112_71932).

Kadınların kendi aralarında farklı sorunları müzakere ettiği forum kısmında da pek çok ürün destek içerik paylaşımı yapıldığı da görülmektedir.

"Merhabalar. Gögüs ucu yaraları için önerebileceğiniz en iyi krem hangisi? Bir de bu "yaraların oluşmasını engellemek adına bebeğin göğsü tam olarak kavramast yani kahverengi yeri ağzına tüm olarak almast gerekiyormuş. Ben bebeğimi boğarım diye çok korkarım ilk gebeliğim, tavsiyesi olan anneler var mi?" (https://www. anneysen.com/hamilelik/ soru-cevap/bebek-hazirliklari-gogus-ucu-catlagi-20190119_72017)

"Ben göğüs ucundaki yaralarla savaşırken tek göğsümden artık emziremez hale geldim ve sütüm inanılmaz azald. Hala tek göğsümle emziriyorum ve bu yüzden ben 1 aylık bile olmadan mama kullanmaya başladım. Mutlaka bu sorunu gidermelisiniz. Bana eşim lansinoh diye bir krem aldı. Biraz pahal diğer ürünlere göre fakat en iyisi diyebilirim. Zaten eczaneye de sorsanız ilk bunu önerecektir size”.

“Fito krem yılların ürünü herkes kullanabilir”. 
“Krem değil de gümüş kapakları kesin öneriririm”.

Benzer sorunları ve tartışma panolarını göz önünde bulunduran site özellikle kadın bedeni ve toplumsal cinsiyetlendirilmiş hali ve annelerin kendilerini en güçsüz hissettikleri (ilk zamanlar çocuğun beslenmesi-beslenememesi özellikle sıklıkla dile getirilmiş) alan üzerinden ürün tavsiyelerinde de bulunmaktadir.

"Anne memesi denen bir gerçek var ve bu gerçek kabul edelim ki bazen çok acı verici oluyor. Dünya Sağglk Örgütü'nün verilerine göre annelerin emzirmeyi bırakmalarının başlıca sebebi göğüs ucu yaraları. Anne sütünün bebek için en iyi besin olduğunu düşündüğ̈̈müzde bu duruma üzülmemek elde değil. Emziren annelerin en büyük sorusu "Göğüs иси yarasına ne iyi gelir?"e cevap olan Silverette gümüs kapakları ile seni tanıştırmak istiyoruz. 1970 yılından bu yana Italya'da Tecnologia Ospedaliera isimli medikal bir şirket tarafindan üretilen Silverette, Türkiye'de 2 yıldır büyük ilgi görüyor".

"Merhaba Ek gldaya geçiyoruz ama henüz tabak vs alamadım. Önerebileceğiniz sağlıksız içerik barındırmayan markalara ihtiyacım var. Hızlı dönüş yaparsanız sevinirim. Şimdiden ilginize teşekkürler”.

"Bunu öneririm ebebekten almıştım ben ama internette bulamadım ebebek mağazalarina sorabilirsiniz tamamen sağlı̆̆a uygun hiç plastik içermiyor misır özütündenü eritip dondurup şekil verilerek üretilmiş doğal içerikli” (https://www.anneysen.com/ilk-yil/soru-cevap/bebekbeslenmesi-ek-gida-icin-tabak-catal-kasik-20190129_72126@).

Annelerin soru sordukları, tartıştıkları panolarda pek çok ürün desteği, marka ve yer isimleri, özel okul-kreş önerileri, beslenmeye ilişkin takviye edici gıda (sadece gıda değil, çatal, kaşık, biberon gibi araçlar da kaygı konusu olmakta), kozmetik ürünleri ve çocuğun hem fiziksel hem de zihinsel gelişimine yönelik aktiviteler yer alarak, anneliğe ilişkin genişleyen bir tüketim alanının nasıl olduğu ve annelerin bunları nasıl pratikte kaygı konusu yaptığını da bize göstermektedir. Dolaysıyla seçeneklerin çokluğu ve ideal annenin sınırlarının bu seçeneklerden en iyisini tüketerek de çizilebileceği gerçeğinin inşası, bitmek bilmeyen bir ürün ve hizmet arayışını beraberinde getirmektedir.

Hamilelik planlama kategorisi altında doğurganlık, yumurtlama dönemi, hamilelik belirtileri, kısırlık ve tüp bebek tedavisi gibi konularda içerik sunan site; aynı zamanda hamilelik döneminde sağlık, beslenme, spor, günlük yaşam, doğum, hamilelik kıyafetleri ve eşyaları, bebek hazırlıkları gibi konularda da hem içerik sunmakta hem de kadınların kendi arasında bilgi alışverişine olanak tanımaktadır. Özellikle doğumdan sonra geniş bir içerik sunan site; çocuk sağlığı ve hastalıkları, çocuk beslenmesi, gelişimi, davranışı, tuvalet eğitimi, uyku, oyun-oyuncak, çocuk eşyaları ve ihtiyaçları, çocuklu yaşam, doğum günü, çocuk odası fikirleri, eğlence gibi konularda annelere teorik bilgiler sunmakta ve ideal bir annelik yaratılmaya çalışılmaktadır. Bu bilgilerin, tüketim pratiği içinde anneliğin ve çocuk büyütmenin her aşamasını önemli bir ticari kaynağa dönüştürerek, kapitalizm ruhuna annelik ideolojisini de entegre ettiği söylenebilir. Kapitalist ideoloji içinde daha fazla kâr getirisi amacıyla kadınlık deneyimleri ve özellikle annelik önemli bir araç haline getirilerek, yeni tüketim alanları ve pazarları yaratılmaktadır. Bedenin, özellikle kadın bedeninin ve sağlığının önemli bir kâr kaynağına dönüşmesinin ardında yatan neden Baudrillard'ın $(2008,163)$ da belirtiği gibi tüketimin beden üzerinden işleyecek çok sayıda pazara sahip olmasıdır. 


\section{Bir Dayanışma Pratiği Olarak Paylaşılan Annelik}

Yeni iletişim teknolojilerinin ve özellikle yeni medyanın gerek bireysel gerekse toplumsal yaşamın her alanına etki ettiği ve yeni ilişki biçimleri ürettiği gerçeği söz konusu çalışma için önemli bir dayanak noktasını oluşturmaktadır. Annelik blogları, diğer sosyal paylaşım platformları çeşitli ülkelerden farklı sosyo-ekonomik düzeye sahip kadınları bir araya getirerek hem tanışma hem de tartışma firsatı sunmaktadır. Söz konusu çalışmanın örneklemini oluşturun site; kadınlık, annelik halleri, çocuk büyütme, emzirme, hamilelik, sağlık ve estetik gibi konularda kadınlara çevrim içi tartışma olanağı sunmaktadır. Kadınlar geleneksel bilgi arayışlarının aksine, interneti ve özellikle sosyal paylaşım ağlarını destek, bilgi kaynağ 1 ve başkaları ile iletişim içinde sorunlarını paylaşmak ve çözmek için kullanmaktadır. Farklı kategorilerde çok sayıda sorun ve içeriğin paylaşıldığı bu mecralar, aynı zamanda kendi içinde terapi gruplarının oluşmasını da berberinde getirmektedir. Ebeveynlik siteleri ve tartışma forumları hakkında çok sayıda sosyal araştırma yapılmakta ve bu araştırmalar çoğu kadınların destek ve bilgi sağlamak için bu sitelere değer verdiğini ortaya koymaktadır (Madge \& O’Connor 2006; Johnson 2016; Lupton 2016). Özellikle kadınların bebek bakımı konusunda kendilerini en çaresiz ve yalnız hissettikleri alanda destek istedikleri, özellikle de bebeğin büyütülmesi sürecinde başka annelerin tecrübelerine başvurduğu gözlemlenmiştir.
"Deneyimli anneler dogum yptim 3 gun oldi bu 2. doğumum doğum esnasinda hepapit $C$ denilen virus hastaliğ çıktı bende. Bu yüzden bebeğimi emziremiyorum bulaşıcı bir hastalık olduğundan doğru diğer oğlumu 15 aylık emdi, fakat bunu emziremiyorum diye çok üzülüyorum ne olur kusura bakmayın uzun oldu özür dilerim hangi mamayı tercih etmeliyim... oğluma vermem için çocuğum şimdi küvezde 3 gündür dünyam alt üst oldu”.
"Merhaba. Benim sütüm yoktu. Evolvia yı tercih etmiştim. Besin değeri yüksek bir mamadir".
"Merhaba çok geçmiş olsun bende 19 günlükte başlamıştım mamaya aptamil kullandım ve bebeğime hiç zararı olmadı gayet să̆glık 7 aylık olduk".

Söz konusu paylaşımlardan anlaşıldığı gibi kadınlar kendi aralarında kaygılarını dile getirmekte, pek çok tavsiye ve telkine ihtiyaç duymaktadır. Lupton'ın 2016 yılında hamilelik ve erken annelikte dijital medyanın kullanımı üzerine yaptı̆̆ bir odak grup çalışmasına göre; kadınlar yalnızlıkları, çaresizlikleri ve kaygıları ile baş edebilmenin yanı sıra; anında, düzenli, özelleştirilmiş, profesyonel ve detaylı bilgi edinme açısından dijital medyayı kullanmaktadır. Odak gruplarından elde edilen en önemli bulgulardan biri de, katılımcıların internette hamilelik ve ebeveynlik hakkında bilgi aramak için arama motorlarını (ve özellikle de Google'ı) sürekli kullanması ve zamana mekana sıkıştırmadan her an çevrim içi ortamda bu bilgi arayışına devam etmeleridir. Hamile kadınlar veya anneler en popüler olan sosyal medya ağlarını bile (Facebook gibi) uzman grupları veya sayfaları aramak için kullanabilecekleri bir platform olarak görmektedir. Kadınların bu bağlamda sadece doğrudan çocuk büyütme pratiği konusunda diğer kullanıcıların tecrübelerinden faydalanmakla kalmadıkları, aynı zamanda bunaldıkları, tıkandıkları ve kendince çözüm üretemedikleri ve dolaylı olarak yine annelik pratiği ile ilgili konularda da destek ve öneri istedikleri görülmektedir. Başka bir çarpıcı nokta ise; kadınlar, gündelik hayat içinde yüz yüze ilişkilerden bıkmış, çaresiz bir şekilde onu tanımayan ve dolayısıyla yargilamayacak annelerden destek taleplerinde bulanabilmektedir. Bu durum annelik pratiği konusunda genç annelerin yargılanmaya maruz kaldıkları gündelik hayatlarından ve yakın 
çevrelerinden kaçış1 da içeren bir süreçtir. Kendisini yargılamadan anlayan ve otorite kurmayan empatik destek gereksinimi satır aralarında vurgulanmaktadır:

"Mahalle baskısından yılmıs bir anne olarak kendimi aranıza attım. Alkış, by by, öpücük bunlar kriter mi gelişimde? 13 aylık ikizlerim var kendilerini oyaladıkları oyuncakları ile vakit geçiren çocuklar. Alkış yapmak ilgisini çekmiyor ilgilenmiyorlar. Insanlar beni yoruyor ve incitiyor. Ne yapmallyım, gelişimlerinde nasil oyuncaklar almaliyım hepsini araştırlyorum. Sizlerinde basına geldi mi böyle şeyler bana da bi el verin :(”

“... Kısaca diğer insanlara çok takılmayın ve çocuklarınızla geçirdiğiniz her anın tadını çıkarın. Kaygınızı onlar da hisseder. (ben artık kızımın yemek yememesine çok takllmıyorum ve sanırım her şey düzelmeye başladı) Mahalle baskısı konusunda başarılar dilerim, çocuklardan çok o yoruyordur eminim. Çocuklarınızı sağllkla ve sevgiyle büyütmeniz dileğiyle...”

Çocuğun bakımına ilişkin her türlü bilgi ve talebe erişilebilen sitede, kadınların çok farklı kategorilerde bilgi ve destek talep edebildikleri gözlemlenmekte; okul ve bakıcı önerisi, annelik ve çocuk büyütmeye ilişkin her türlü ürün talebi gibi konularda kendi içinde bir destek ağ oluşturdukları da görülmektedir. Modern hayatın getirdiği yoğun ve aynı zamanda ataerkil ideolojinin dayattığı yeni annelik miti, çocuğun her aşamada bakımına ilişkin sorumluluğu ve dolayısıyla bilgi arayışını kadının sorumluluğuna bırakmaktadır. Kadınlar, bu sorumluluğu sanal bir platformda kendi ile aynı rol ve sorumluluğu paylaşan kadınlarla birlikte müzakere etmektedir.

"Çalışan bir anne olarak bakıcılardan yana çok sıkıntı yaşadım. Ataşehir bölgesinde 4 yaşındaki kızımı uzun zamanlı bırakabileceğim güvenilir, temiz bir oyunevi arlyorum. Bildiğiniz bir yer var mı?”

“Ataşehir'de 2 yıldır oğlumu gönderdiğim İstanbul Kids Club'ı tavsıye edebilirim. Clup sabah 9 dan aksam 9'a kadar açık hem İngilizce hem spor aktiviteleri de yer alıyor. Hostes olarak çalıştığım için benim için ideal. Bazen Cumartesi - Pazar bile işe gittiğim günlerde bırakabiliyorum”.

Benzer sorunları deneyimleyen annelerin birbiriyle tecrübelerini paylaştığı ve çözüm $\operatorname{arad} 1 \mathrm{~g} 1$ görülmekte, yeni bir sosyal ilişki ağı da geliştirilebilmektedir. Lupton’a (2016) göre kadınlar, çeşitli uygulamalara ve çevrim içi medya tarafindan sunulan bilgilere değer atfetmekte ve bu ağlar samimiyeti veya kişisel bilgileri paylaşmaya aracılık ederek, sosyal ilişkilere katkıda bulunma kapasitesine sahip olabilmektedir. Bu durum bazı hamilelik ve ebeveynlik uygulamaları, web siteleri ve danıştıkları sosyal medya platformları tarafından sunulan çevrim içi forumlar için geçerli olabilmektedir. Katılımcılar, deneyimlerinin ayrıntılarını diğer annelerle paylaşabilmenin ve gerektiğinde tavsiyede bulunmanın önemini de vurgulamışlarıdır.

" 8 haftalık kizim var kızımda bugünlerde bazı değişiklikler oldu artık gaz problemimiz biraz daha azald kendi kendine oyalanabiliyor el ve bacakları daha çok hareketlendi ama uyku düzenimiz daha kötüye gitti gece 1520 dk da bir uyaniyor uykuya derin dalmıyor gündüz uykumuz iyi ama gece çok sıkıntı oluyor bu dönem geçici mi bu sorunu yaşayanlar ne zaman nasll düzene gireriz" 
"Merhaba bebekler bu dönemde çeneleri yorulduğu için karınlarını tam doyuramazlar o yüzden sürekli uyanıp emmek ister ama bu seferde uykusu olduğu için tam emip karninı doyuramaz. Ben bebeğime 25 günlükken anason ve rezene çayl verdim bir çay kaşı̆̆ doktorumuz verebilirsin demişti ve çok rahatlamıştı. Ama size bir tavsiye vermek isterim nacizane. Benim başıma geldi ve şimdi baya sorun yaşlyorum. Her uyandiğında meme verirseniz ilerde memede uyumaya alışacak ve anneyi emzik yerine koyacak ve sürekli sizi yoracak. Karninı tam doyurduğunuza emin olursanız ve bu sürede uyanır da onu pışpışlayarak uyutmaya çalışın. Buna alışmazsa ilerde çok zorlanacaksınız. Allah yardımcınız olsun. Sağllkla büyütün inşallah" https://www. anneysen.com/ilk-yil/soru-cevap/yenidogan-uyku-duzenimiz-ne-zamanoturur-20190205_72188

Kadınlar annelik süreci ile başa çıkmak için bilgi ve güven arayışına girerek, kaygılarını azaltmak için teknoloji ve çevrim içi desteklere başvurabilmektedir. Blog ya da sosyal paylaşım siteleri annelerin hem benlik duygularını korumaya hem de yeni bir kimlik oluşturmalarına yardım etmede kilit rol oynayarak, onlara bir çeşit terapi imkanı sunmaktadır (Gibson \& Hanson 2013). Aşağıda yer alan paylaşımdan da anlaşılacağı gibi sadece anneliğe ilişkin süreç ve sorunlar değil, aynı zamanda gündelik hayata ve özel ilişkilere yönelik sorunlar da müzakere edilebilmekte ve bu konularda destek ihtiyacı duyulmaktadır. Bu süreç sosyal ilişki ağı içinde yeni bir dayanışma örüntüsünü doğurduğu gibi yeni sosyallikler de yaratabilmektedir. Sorucevap panoları kadınların dertleștiği bir platforma da dönüşmeye başladığı ve önerilerin samimi bir dil ve empatik bir duygu ile yapıldığı görülmüştür.

"13 aylik bir oglum var. Ilk defa anne oldum ama 10 yillik kresde calismisligi var. Oglum benim herseyim. Ama esimle aramiz hic iyi degil. Onun her hareketi ve sozleri beni rahatsiz ediyor. Surekli tartisiyoruz. Kafamda her gun bosuyorum onu. Oysa bebekden once cok mutluyduk. Cok cabuk sinirleniyorum oglun ile ilgili herseyde cok hassasim. Hala emziyorum, geceleri cok uyaniyor. Uykusuzluga tahammulum kalmiyor. Hayatimi duzene sokamadim. Her sabah duzenli spor yapan, saglikli beslenen benden eser yok. Oglumu u hala ben besliyorum. Kendisi yemiyor. Ev isine, yemek yapmaya yetisemiyorum. Depresyondamiyim? Benim gibi hisseden var mi?"

"Merhaba Eda Hanımcı̆̆ım, üzerinizde hem çocuğun hem evin sorumluluğunu taşıyorsunuz. Eşiniz de bu süreçte size yardımcı olmuyor anladığım kadarıyla. Bu süreç uzadıkça kendinizi yetersiz hissetmeniz kaçınılmaz. Sizinle benzer yollardan bende geçtim. Detaya girmeyeceğim. Naçizane tavsiyem, eşinizden ev ve çocuk bakımı için yardım talep edin, açık açık sıkıntılarınızı (tartışmaya girmeden) anlatın. Mümkün ise bir akrabanızdan haftada bir kaç saat çocuğunuza bakmasını rica edip, eşinizle başbaşa vakit geçirin. En önemlisi de şudur ki, ev işlerini çok kafanıza takmayın, önemli olan sizsiniz ,sonra çocuk, sonra eş geliyor. Sizin psikolojiniz iyi olusa, inanın çocuk da daha sakin olur. ev işleri, temizlik konusunu çocuğunuz 2,5 yaşına gelene kadar en arka plana atın. inanın bana işler yetişmiyor ne yaparsanız yapın. öncelik sizin mutluluğunuz, sonra çocuğunuzun ve eşinizin. Hayatın tadını çıkarmanız dileğiyle. sevgiler...” https://www.anneysen.com/ilk- 
yil/soru-cevap/bebekle-yasam-depresyon-mu-acaba-20181122_71420

"Bebeğim 3 aylık 3 aydır evde hapisim ve gerçekten bunalıma girdim kafay yemek üzereyim neden doğurdu mu sorgulamaya başladım. Allah muhafaza korkuyorum”

"3 aylık bebek annesi olarak söylüyorum geçecek nolur sabredin. Çok yorucu bir süreç insan duygu durum bozukluğu yaşıyor. Ben annem neredeyse 24 saat yanımda olmasına ve bebeği sürekli alı beni dinlendirmesine rağmen berbat haldeydim. Ama bebeğinizin tek ihtiyact sizsiniz o sadece sizi taniyor güveniyor istiyor. Nolur biraz daha gözünüzğ kapatın. Bir de dilek cesurun seni anliyorum çocuk kitabını okuyun. Çok iyi geliyor." https://www.anneysen.com/ilk-yil/soru-cevap/ depresyondayimmmm-20181114_71357

Bu tür sitelerin anonimleştirilmesi, kullanıcıların yüz yüze iletişim normlarıyla kısıtlanmadığı ve ailelerini özellikle de kocalarını diğer üyelere serbestçe eleştirebilecekleri anlamına gelir (Madge \& O’Connor 2006; Schoenebeck 2013; Pedersen 2014). Değişen iletişim biçimi; sorunların daha rahat ifade edilmesine, önerilerin de açık bir şekilde ve kişisel deneyime dayanarak dile getirilmesine de neden olmaktadır. Anneliğin farklı formları ile yüzleşen ve sosyal hayatın yarattığı baskının yükünü taşıyamayan birçok kadın, bu panoları önemli psikolojik destek aracı olarak da görebilmektedir

"6 aylik bebisim var. Ama ölüm korkisu intihar korkusu ve bebege zarar verme düsünceleri. Tedavi görüyorum ama bu tedavi başarlya ulaşacak mı ilaçlar ne kadar düzeltir beni”

"emin ol faydasinı göreceksin. Eski haline döneceksin. Bende çok kötü zamanlar geçirdim. Yardım edecek kimse yoktu tek başıma saatlerce ă̆layan bir bebeğim vardı. Gazlı bir bebekti saç kurutma makinası ve elektrik süpürgesi sesiyle duruyodu sadece o seslerlerden o $k d r$ bunalmışım ki inan evi zoraki süpürüyorum o sesi duymamak için saçımı bile çok nadir kurutuyorum. Bende delirecek gibiydim doktora gitmeyi düşündüm ama gitmedim sen iyiki gitmişsin daha çabuk atlatırsın emin ol :) Benim nasil atlattı̆̆ıma gelirsek geçeceğini düşündüm hep ve kendimi inandirdim. 5 aylik olduktan sonra da bebegim de düzeldi bende :) Kendine inan ve güven. Yaşamış biri olarak söylüyorum yakında geçecek emin ol. Hayattan zevk almaya bebeğini sevmeye odaklan hersey güzel olacak :))" https://www.anneysen.com/ilk-yil/soru-cevap/dogumsonrasi-anne-deren14-20181111_71334

Kadınlar sadece çocuk bakımı konusunda değil özel ve gündelik yaşam içinde karşılaştığı ve karşılaşabileceği sorunlar üzerine müzakere etmekte, fikir alışverişi yapmakta ve çeşitli alanlarda desteğe ihtiyaç duyabilmektedir. Özellikle yüz yüze ilişkilerde konuşulamayan, mahrem alanın sınırları içine girdiği düşünülen sorun ve sıkıntılar sanal etkileşim ortamında daha kolay dile getirilebilmektedir. Kadınların annelik kimliği ve geleneksel aile rolleri ile başa çıkamadıkları ve bu yüzden zaman zaman bu iki rolün çatıştığı görülmektedir. Bu mecralar; benzer süreç ve sorunları yaşamış, başka bir kadınlık deneyimi ile yüzleşmenin ve birbirine sığınmanın uğrak yeri haline de gelebilmektedir.

"ya ben 25 haftalık hamileyim ve daha cocugumla ilgili kiyafet tir vs .. bise alamadım aldırmıyor neymiş erkenmis hastaneye sık gidiyordum die 
onada laf ediyor lbucuk aydir öyle dedi die gitmiyorum geçen sancılandım acile gittik birde erken doğum riski var dendi halde her şeye erken diyor beraber yaşıyoruz kizlar sizce napmak gerek"

“Merhaba güzel anne adayı eğer şimdi sana bu kadar karlşlyorsa bebeğin doğduğunda bebeğinin üzerinde de çok baskı kurabilir en iyisi sen şimdiden müdahalede bulun sonra üzülürsen sütün kesilebilir hem şuan bu kadar stres bebek için iyi değil bence düzenli olarak muayenelerine devam et ona çok kulak asma tatlı tatlı alışverişini уар...”

"Aynı sorunu ben eşimle yasadim alışverişe gitmedik erken diye ama erken doğum riskini olduğu için ve 36haftalikken dogumum başladı hiçbir şey olmadan hastaneye gittik bebeği saracak kundağ bile yoktu sen bence eşinle alışverişe git kaynananida umursama..."

"imkanin varsa annenin evine git stresten uzaklaş hem sana hem bebeğine büyük zarar..." https://www.anneysen.com/hamilelik/sorucevap/bebek-hazirliklari-kaynanamdan-imdatt-20181123_71438

Wilson ve Yochim'e $(2017,16)$ göre Dijital dünya anneler için toplumsal cinsiyetlendirilmiş bir alandır. Sınırsız içerik ve tavsiyeye sahip olabilen dijital gündem, sürekli bilgi ilham ve firsatla örtüşen bir anne dünyasına dönüşmektedir. Ebeveynlik ürünleri satan ve tavsiye veren BabyCenter gibi kurumsal web siteleri; kadınlaştırılmış sosyal medya platformları; annelerin önemli duygusal ve maddi destek biçimleri bulduğu annelik alanlarıdır.

$\mathrm{Bu}$ dijital annelik alanları kadınların deneyimlerinin temsil edildiği, tartışıldığg ve yeniden üretildiği, geleneksel annelik temsillerine de meydan okuyarak yeni annelik kimlikleri de yaratmaktadır (Friedman 2013). Anneler bu anlamda sadece bilgi ve tecrübelerini ikame etmemekte, aynı zamanda çok çeşitli ürünleri (bebek kıyafetleri ve ürünleri, anne sütü) talep edilebilmektedir. Ücretsiz çok sayıda paylaşımın yanı sıra ücretli satışlar da söz konusu olabilmekte, kadınlar sanal ortamda yeni bir dayanışma pratiği yaratarak hem duygusal hem maddi destek sağlamaktadırlar.

\section{Bir Uzmanlık Alanı Olarak Yaratılan Annelik}

"Anneliği sizin için kolaylaştırlyoruz" sloganıyla başlayan sitenin özellikle uzman desteğini ön plana çıkartması ve uzmanlara soru sorma firsatını sunması; anneliğin bir teorik bilgi haline de gelmesine öncülük etmektedir. Hamile kadınların ve küçük çocukları olan annelerin, çevrim içi kaynaklar ve uygulamalar kullanarak aldıkları bilgi ve desteğe büyük önem verdikleri; dijital teknolojileri kullanarak bilgiye ve profesyoneller tarafından sunulan içeriklere daha iyi erişmek istedikleri yapılan çalışmalarla da ortaya konulmaktadır. Çoğu kadın; ebe, çocuk doktoru veya çocuk hemşiresi gibi sağlık uzmanları ile canlı bir soru-cevap çevrim içi forumu veya görüntülü görüşme sunan bir teknolojiyi önemsediklerini ifade etmiştir (Lupton 2016). Bu ampirik bilgiden hareketle profesyonel ürün, hizmet ve uzman desteğinin en çok işlenen ve talep edilen konular arasında olduğu gözlemlenmektedir. Üyeler, farklı alanlardaki çeşitli uzmanlara doğrudan soru sorma imkanına sahip olmanın yanı sıra (beslenme diyet, çocuk hastalıkları, çocuk kitapları, hamile danışmanı, evlilik danışmanı, alışveriş kıyafet danışmanı, finans, doğum terapisi, hukuk, iç mimar, cinsel eğitim danışmanı, spor, tamamlayıcı tıp, -doğal ve organik ürünler koçu, isim bilimi, uyku koçu, sağlık-güzellik... Vb 46 farklı uzmanlıklar) aynı zamanda uzman videoları ile çeşitli pratik ve teorik-bilimsel bilgilere de ulaşabilmektedir.

\section{“Uyku Danışmanı Melis Keşan, bebeğin kendi kendine uykuya dalmasını}


sağlayacak şartları anlatıyor!”

“Nefess Yoga'nın çocuk yogası ĕgitmeni Gökçe Ayyıldız'a derslerin nasıl geçtiğini ve nasıl egzersizler yapıldiğını sorduk."

"Çocuk yetiştirirken ebeveyn tutumlarındaki farklılı̆̆ııın partner ilişkisini nasıl etkilediüini Evlilik ve İlişki Danışmanı Yeşim Varol Şen ile konuştuk, hemen izle!”

Örneklerden de anlaşıldığı gibi son yıllarda çok farklı uzmanlık alanları aracılığıyla uzmanların gündelik hayat içinde bireylerin ilişki biçimlerini yönetme imkanı elde ettikleri iddia edilebilir. Alı̧̧-veriş, moda, sağlık, evlilik, çocuk bakımı, spor, finans ve benzeri alanlarda kendilerini danışman ya da koç olarak tanımlayan çok sayıda uzman ortaya çıkmakta, bireylere farklı kategorilerde ürün ve hizmet sunmaktadır.

"Bebeğinin gelişimini desteklemek için hangi oyuncakları seçmelisin? Uzman Klinik Psikolog Ipek Gökozan tüm detaylarlyla anlattı!”.

"Çocuk Sağllğı ve Hastalıkları Uzmanı Dr. Dicle Inanç, 19 aylık bebek gelişimi ve uyku ĕgitimi konularında bilgi verdi!" (https://www. anneysen.com/ilk-yil/videolar).

"Çocuğun kreşe başlaması için uygun zaman nedir? Bu süreç nasıl kolaylaştırılır? Uzman Klinik Psikolog İpek Gökozan yanıtllyor!”.

"Bebeğinin hem yaşıtlarlyla sosyalleştiği hem de kaba motor becerilerinin geliştiği oyun atölyelerinin faydalarını ögrenmek için StudioBee'nin kurucusu Zeynep Hanım ile konuştuk.

Yüzme Eğitmeni Yasemin Çulha'dan bebek yüzme aktivitelerini hemen dinlemeye başla!".

"Bebeğin ilk dişlerini çıkarttı ve artık bebek diş sağlığına dair kafanda soru işaretleri oluşmaya mı başladı? Aynı zamanda diş hekimi de olan sunucumuz Nejla, bebek diş firçası seçerken nelere dikkat etmen gerektiğini anlattyor" (https://www.anneysen.com/1-6-yas-cocuk/videolar).

Giddens’a göre uzmanlık ve uzmanlaşma modern dönemin temel sonuçlarından biri olarak ortaya çıkmış, uzmanların sahip oldukları bilgi seküler bir anlayışla herkesin ulaşabileceği ve erişebileceği bilgiye dönüşmüştür. Dolayısıyla modern dünyanın bireyleri de hayatın bazı alanlarında uzmanlaşmakta, uzman bilgiye kolaylıkla erişebilmektedir (Giddens \& Pierson 2001, 101). Bauman’a $(2003,255)$ göre, günümüzde bireyler birçok alanda uzman desteğine ihtiyaç duymakta ve bu desteği talep etmektedir. Uzman, bireyin içinde bulunduğu nesnel ve öznel dünya (bireysel ve toplumsal dünya) arasında köprü görevi görmekte, onlar adına karar vererek belirsizliği aşmada yardım etmektedir. "Uzman, aynı anda, hem güvenilir ve kişi-üstü bilginin kaynağını soruşturma hem de bir kişinin en derin düşünce ve özlemlerini anlama kapasitesine sahip bir insandır; yorumlayıcı ve aracı bir kişi olarak, nesnel ve öznelin aynı dünyaları arasındaki köprüdür.” Uzman, bilimin doğru karar alma gücünden beslenerek, bireyler adına seçim yapabilmekte ya da bu seçimi yönlendirebilmektedir. Bauman (2003, 273) bu durumu "bireyin hem doğa hem de toplumla iliş̧kisi, uzman becerileri ve bunlara eşlik eden teknoloji aracıllğglyla yürütüldüğü zaman, yaşam etkinliklerinin kumandası, becerilere sahip olan ve teknolojiyi yönetenlerin eline geçiyor” diyerek de eleştirmektedir.

Bireyler bir yandan artan iletişim teknolojileri ve özellikle internet, akıllı telefonlar sayesinde kolaylıkla farklı bilgi türlerine ulaşma şansı elde ederek, kendi hayatının uzmanı haline 
gelmekte; öte yandan online destek ve danışmanlık hizmeti alabilmektedir. Uzmanlık bilgisi daha şeffaflaşarak, bireyin kullanımına sunulurken, uzmanlıklar da alt uzmanlıklara ayrılarak kendi içinde hiyerarşik bir ilişki geliştirmektedir. Bu hiyerarşik ilişkiye bir "en doğru”, "en iyi”, "en ideal" bilgi eklemlenerek, anneliğe ilişkin yeni teorik alanlar da tartışılmaktadır. En doğru uyutma şekli, en geliştirici aktivite, en iyi emzirme yöntemi, en iyi fit kalma egzersizleri, en iyi okul gibi hep biraz daha iyi slogan ve anlayışıyla üretilen içerikler uzman desteği ile oluşturulmaktadır. Bu süreç, anneliği artık deneyime dayanan bir pratik olmanın ötesine geçirerek, belli kurallar, ölçütler ve teorik bilgiler ışığında yeniden inşa edilecek bir alana dönüştürmektedir. Sadece uzman bilgisi değil aynı zamanda kullanılan her uygulama, sosyal medya platformu veya bloglar bu sürecin bir parçası olarak önemli rol üstelenmektedir.

\section{Sonuç}

Bireysel farklıkları ve farklı kadınlıkları göz ardı eden yeni medya; anneliğin nasıl yaşanılması gerektiği, ideal sınırlarının neler olduğu, iyi doğru ve mükemmelliğin ölçütlerini belirleyerek standart hakikatler üretme çabası içine girmektedir. Bir yandan standart hakikatler üretilirken, öte yandan kadınlığa ilişkin alanlar ve deneyimler birer tüketim pratiğine dönüştürülerek yeni pazarların yaratılmasına aracılık edilmektedir. Özellikle yüzyıllar boyunca toplumsal cinsiyet rolleri bakımdan kadının konumunu ve statüsünü belirleyen, kadınlık kimliğini oluşturan kutsallaştırılmış annelik de, bu pratiklerden biri olarak görülmüştür. Kadın bedeninin doğrudan doğurganlığın ve ataerkil ideolojin merkezinde yer alması, kapitalist ideolojiye kolay eklemlenesini sağlayarak bu pratikleri güçlendirmiştir. Hamilelik öncesi süreçle başlayan ve bunu takiben, hamilelik, doğum, doğum sonrası ve çocuğun büyütülmesi gibi farklı evrelere yönelik çok sayıda ürün ve hizmet dijital medya aracılığıyla da sunulmaya başlanmıştır.

Dijital medya son yıllarda tüm dünyada toplumsal, ekonomik ve siyasal hayatın her yanını kuşatarak, yeni ilişki formlarının da üretilmesine kaynaklık etmekte, yeni toplumsallıklar yaratmaktadır. Özellikle son yıllarda her geçen gün popülerliği artan sosyal medya platformları ve internette çok sayıda diğer çevrim içi sohbet ve destek sunan siteler bu ilişki formlarının dönüşmesinde etkili olan araçlar olmaktadır. Farklı amaçlarla bir araya gelen gruplar, politik ağlar oluşturabilmekte; ekonomi, moda, estetik, sağlik, cinsellik, aşk, ebeveynlik gibi konularda bilgi, destek ve dayanışma örüntülerini paylaşabilmektedir. Son yıllarda tüm dünyada talep edilen ebeveynlik siteleri de bunlar arasındadır. Özellikle çocuk yetiştirme pratiklerinin uzmanlık içeren bir formata bağlanması, iyinin, doğrunun ve mükemmelliğin ölçütlerinin belli kural ve standartlarda tanımlanmasını sağlamakta ve bu durum çocukların bakımıyla sorumlu tutulan kadınların doğrudan bu siteleri talep etmesini de beraberinde getirmektedir.

Söz konusu çalışmada ele alınan anneysen.com sitesi doğrudan anne olmak isteyen ve anne olan kadınlara ürün, hizmet ve uzman desteği sunmakta, anneliğin tüm pratiklerini önemli bir tüketim alanına dönüştürmektedir. "Anneliği sizin için kolaylaştırıyoruz" sloganıyla içerik oluşturan site; anneliği uzman alıcı bir pratiğe dönüştürebilmekte kadının bedeni ve doğurganlığı üzerinden çok sayıda öneri, hizmet ve ürün tavsiyesinde bulunmaktadır. İyi veya doğru anneliğin sınırları aldığınız destek ve hizmet çeşitliğine göre de belirlenmektedir. Ataerkil ideoloji, kapitalizm ve teknoloji iş birliği içinde bu sürecin baş aktörü olarak çocuğun bakım ve büyütme pratiğini annenin sorumluğuna bırakarak, ona yönelik yeni pazarlar oluşturmakta ve çok sayıdaki seçenek içinde seçim sorumluğunu da ona bırakmaktadır. Kadın bedeninin, dogurganlığının ve cinselliğinin üzerinden söz sahibi olan kapitalist ve ataerkil ideoloji teknolojik araçlar yardımıyla kendini yeniden üretirken, kadınlar bu ideolojiler ile baş edebilmek için çok sayıda strateji ve yöntem de geliştirmektedir. Söz konusu çalışmada incelenen ve doğrudan anne olmak isteyen ve anne olan kadınlara yönelik içerik ve tartışma panoları oluşturan site, bir yandan anneliği uzman destekli ve çok sayıda pazar odaklı bir pratiğe dönüştürürken; öte 
yandan kadınların bütün bunlar üzerine müzakere edebileceği, sorunlarını, bilgi ve deneyimini paylaşabileceği, bebek ürünlerini takas edebileceği, yalnızlığını giderebileceği bir ortam olanağı da sunmaktadır. Kadınlar, gündelik hayat içinde yüz yüze iletişimde açık bir şekilde dile getiremediği, konuşamadığı ve başkalarıyla doğrudan paylaşmadığı sorunları, sanal platformda daha rahat yazmakta ve yardım talep edebilmektedir. Özel hayatında yaşadığı sorunları kendisini yargılamadan cevap verecek, samimi bir ortam ve destek arayan anneler; yeni bir dayanışma örüntüsünün oluşmasına da katkıda bulunmaktadır.

Çok sayıda öneri, ürün, hizmet ve aktivite ile desteklenen yeni annelik ideolojisinin, aynı zamanda ne yaparsa yapsın yetemeyen bir annelik psikolojisi de yarattığı söylenebilir. Tüketim kültürünün mantığıyla paralellik gösteren bu durum; mükemmel annelik ideolojisinin oluşmasına katkı sağlayarak, bireyin sürekli kendini eksik ve yetersiz hissetmesine ve hiçbir zaman mükemmellik duygusuna ulaşamamasına da neden olmaktadır. Bu durumun paylaşılan içerikler ve tartışma panolarına da yansıdığı görülmekte, anneler bebeğin temel bakımı, sağlığı, beslenmesi ve eğitimi konusunda sıklıkla kaygılı sorular sormakta, kişisel tecrübelerden ve uzmanlardan çeşitli destek arayışlarına girmektedir. Özellikle yeni anne olanların en çok yaşadığı ve dillendirdiği kaygı bebeğini yeterince besleyip beslemediği, uyku sorunu ve temel bakımı olurken; daha sonraki aşamalarda eğitim, aktivite ve zaman geçirmek gibi durumların önemli birer kaygı alanına dönüştügü görülmektedir. Bir yandan yeterli-yetersiz anne tartışması süregiderken, öte yandan bu tarz sitelerin kadınlara kendi sorunlarını başkaları ile tartışma ve müzakere etme olanağı sunduğu görülmektedir. Bu mecralar yeni bir etkileşim ortamı sunmakla birlikte, yeni annelik biçimleri, idealleri ve ideolojileri de üretebilmektedir. Geleneksel, deneyime dayanan ve kuşaktan kuşağa aktarılan birçok yöntem ve anlayışın; yerini, sanal ortamda kendi içinde destek grupları olarak oluşan kadınların paylaşımına bıraktığı söylenebilir.

\section{KAYNAKÇA}

Badinter E. (1992). Annelik Sevgisi: 17. Yüzyıldan Günümüze Bir Duygunun Tarihi. Çev. K. Çelik. İstanbul 1992.

Baudrillard J. (2008). Tüketim Toplumu. Çev. H. Deliceçaylı \& F. Keskin. İstanbul 2008.

Bauman Z. (2003). Modernlik ve Müphemlik. Çev: İ. Türkmen. İstanbul 2003.

Douglas S. \& Michaels M. (2004). The Mommy Myth, the Idealization of Motherhood and How It Has Undermined Women. New York 2004.

Duggan M \& Lehnhart A. (2015). "Parents and Social Media”. Pew Research Center. Retrieved from http://www.pewinternet.org/2015/07/16/parents-and-social-media/

Firestone S. (1993). Cinselliğin Diyalektiği. Çev. Y. Salman. İstanbul 1993.

Forcey L. R. (1994). "Feminist Perspective on Mothering and Peace”. Eds. E. N. Glenn, G. Chang \& L. R. Forcey, Mothering: Ideology, Experience and Agency (1994) 355-377. London.

Friedman M. (2013). Mommyblogs and the Changing Face of Motherhood. Toronto 2013.

Gibson L. \& Hanson V. L. (2013). "Digital Motherhood: How Does Technology Help New Mothers". Proceedings of the SIGCHI Conference on Human Factors in Computing Systems (2013). Paris. Doi: 10.1145/2470654.2470700.

Giddens A. \& Pierson C. (1998). Modernliği Anlamlandırmak. Çev. S. Uyurkulak \& M. Sağlam. İstanbul 1998.

Glenn E. N. (1994). "Social Constructions of Mothering: A Thematic Overview”. Eds. E. N. Glenn, G. Chang \& L. R. Forcey, Mothering: Ideology, Experience and Agency (1994) 1-33 London.

Hall S. (1994a). "İdeolojinin Yeniden Keşfi: Medya Çalışmalarında Baskı Altında Tutulanın Geri Dönüşü”. Ed. M. Kü̧̈ük, Medya, İktidar, İdeoloji (1994) 57-103. Ankara.

Hall S. (1994b) “Kültür, Medya, İdeolojik Etki”. Ed. M. Kü̧̈ük, Medya, İktidar, İdeoloji (1994) 169-209. Ankara.

Hampton K., Goulet L. S \& Purcel K. (2011). "Social Networking Sites and our Lives: Summary of Findings”. Pew Internet and American Life Project. Retrieved from http://www.pewinternet.org/ 
Reports/2011/Technology-and-social-networks/Summary.aspx

Hays S. (1996). The Cultural Contradictions of Motherhood. Yale 1996.

Irigaray L. (2006). Ben Sen Biz, Farklılık Kültürüne Doğru. Çev. S. Büyükdüvenci \& N. Tutal. Ankara 2006.

Johnson S. (2014). "Maternal Devices, Social Media and the Self-Management of Pregnancy, Mothering and Child Health”. Societies 4/2 (2014) 330-350.

Lupton D. (2000). “A Love/Haterelationship’: The Ideals and Experiences of First- Time”. Mothers, Journal of Sociology 36/1 (2000) 50-63.

Lupton D. (2016). “The Use and Value of Digital Media for Information About Pregnancy and Early Motherhood: A Focus Group Study”. BMC Pregnancy and Childbirth 16/1 (2016) 1-10. Doi: 10.1186/s12884-016-0971-3

Lupton D. (2017). “'It just Gives Me a Bit of Peace of Mind’: Australian Women’s Use of Digital Media for Pregnancy and Early Motherhood”. Societies 7/3 (2017) 1-13. Doi: 10.3390/soc7030025

Lupton D., Pedersen S. \& Thomas G. M. (2016). "Parenting and Digital Media: From the Early Web to Contemporary Digital Society”. Sociology Compass 10/8 (2016) 730-743. Doi: 10.1111/soc4.12398

Madge C. \& O’connor H. (2006). "Parenting Gone Wired: Empowerment of New Mothers on the Internet?”. Social \& Cultural Geography 7/2 (2006) 199-220. Doi: 10.1080/14649360600600528

Moore H. L. (2003). “Mothering and Social Responsibilities in a Cross-Cultural Perspective”. Ed. E. B. Silva, Good Enough Mothering? (2003) 58-75. London

Özdemir M. (2010). "Nitel Veri Analizi: Sosyal Bilimlerde Yöntembilim Sorunsalı Üzerine Bir Çalışma”. Eskişehir Osmangazi Üniversitesi Sosyal Bilimler Dergisi 11/1 (2010) 323-343.

Pedersen S. \& Lupton D. (2018). “'What Are You Feeling Right Now?’ Communities of Maternal Feeling on Mumsnet”. Emotion, Space and Society 26 (2016) 57-63. Doi: 10.1016/j.emospa.2016. 05.001

Pedersen S. \& Smithson J. (2010). “Membership and Activity in an Online Parenting Community”. Ed. R. Taiwo, Hand-Book of Research on Discourse Behavior and Digital Communication: Language Structures and Social Interaction (2010) 83-103. Pennsylvania

Pedersen S. (2016). "The Good, the Bad and the 'Bood Enough' Mother on the UK Parenting Forum Mumsnet”. Women’s Studies International Forum 59 (2016) 32-38. Doi: 10.1016/j.wsif.2016.09.004

Rothman B. K. (1994). "Mothers and Fathers: Ideology in a Patriarchal Society”. Ed. E. N. Glenn, G. Chang \& L. R. Forcey, Mothering Ideology, Experience, and Agency (1994) 139-157. London.

Silva E. B. (2003). “Introduction”. Ed. E. B. Silva, Good Enough Mothering? (2003) 1-9. London.

Smart C. (2003). “Deconstructing Motherhood”. Ed. E. B. Silva, Good Enough Mothering? (2003) 37-57. London.

Song F. W., West J. E., Lundy L. \& Dahmen N. S. (2012). "Women, Pregnancy and Health Information Online: The Making of Informed Patients and Ideal Mothers”. Gender \& Society 26/5 (2012) 773798. Doi: 10.1177\%2F0891243212446336

Thomas G. M. \& Lupton D. (2015). "Playing Pregnancy: The Ludification and Gamification of Expectant Motherhood in Smartphone Apps”. M/C Journal 18/5 (2015) 1-16.

Thurer S. L. (1994). Myths of Motherhood. Boston 1994.

Wilson J. A. \& Yochim E. A. (2017). Mothering Through Precarity Women's Work and Digital Media. USA 2017.

Zhou M. (2017). “Motherhood, Employment, and the Dynamics of Women’s Gender Attitudes”. Gender \& Society 31/6 (2017) 751-776. Doi: 10.1177\%2F0891243217732320

\section{İnternet Kaynakları}

https://www.anneysen.com

https://www.babycenter.com/about 